\title{
PHYLOGENETIC IDENTIFICATION OF TWO EXTREMELY HALOPHILIC ARCHAEON ISOLATED FROM RAW HIDE AND INVESTIGATION OF THEIR LIPOLYTIC ACTIVITIES
}

\section{IDENTIFICAREA FILOGENETICĂ A DOUĂ ARCHAEA EXTREM HALOFILE IZOLATE DIN PIEI CRUDE ŞI INVESTIGAREA ACTIVITĂTILOR LIPOLITICE ALE ACESTORA}

\author{
Gözde TURHAN BILGi ${ }^{1}$, Binnur MERiçLi YAPICI ${ }^{*}$, Sadi Turgut BíLGi ${ }^{3}$ \\ ${ }^{1}$ Biology Department, Graduate School of Natural and Applied Sciences, Canakkale Onsekiz Mart University, 17020, \\ Çanakkale, Turkey, gzdtrhn@hotmail.com \\ 2Department of Biology, Faculty of Arts and Sciences, Çanakkale Onsekiz Mart University, 17020, Çanakkale, Turkey, byapici@comu.edu.tr \\ ${ }^{3}$ Department of Midwifery, School of Health, Canakkale Onsekiz Mart University, 17020, Çanakkale, Turkey, stbilgi@comu.edu.tr
}

PHYLOGENETIC IDENTIFICATION OF TWO EXTREMELY HALOPHILIC ARCHAEON ISOLATED FROM RAW HIDE AND INVESTIGATION OF THEIR LIPOLYTIC ACTIVITIES

\begin{abstract}
This research serves two different purposes. Primarily, two extremely halophilic archaeons were isolated from salted raw hide samples and were phylogenetically identified by 16S rRNA sequence analyses. It was determined that isolate 1 shared similarities with Halomicrobium zhouii strain 144 and isolate 2 with Haloarchaeon strain 129. These results were substantiated by some phenotypic analyses. Both strains displayed Gram-negative reactions and they were susceptible to the antibiotics bacitracin and novobiocin. It was qualitatively determined that they have lipolytic activity. Secondly, esterase and lipase enzyme activity conditions of the two archaea were also determined in the current study to evaluate industrial applicability of these enzymes. For the identification of quantitative esterase and lipase activities of both strains, p-nitrophenyl butyrate and p-nitrophenyl laurate substrates were used, respectively, and their activities were measured on a daily basis. After the quantitative and qualitative determination of esterase and lipase activities, esterase and lipase activities were determined at different temperatures $\left(4-60^{\circ} \mathrm{C}\right)$, $\mathrm{pH}$ levels $(4-11 \mathrm{pH})$ and in $\mathrm{NaCl}$ concentrations $(0-5.5 \mathrm{M})$. According to daily enzyme activity results, the highest esterase and lipase values for isolate 1 were found to be $4 \mathrm{U} / \mathrm{ml}$ and $1 \mathrm{U} / \mathrm{ml}$, respectively, on the $4^{\text {th }}$ day and for isolate 2 to be $2.7 \mathrm{U} / \mathrm{ml}$ and $1.9 \mathrm{U} / \mathrm{ml}$, respectively, on the $3^{\text {rd }}$ day. Furthermore, the maximum esterase activity for isolate 1 was elicited at $35^{\circ} \mathrm{C}, \mathrm{pH} 8$ and in $2.5 \mathrm{M} \mathrm{NaCl}$, and for isolate 2 at $35^{\circ} \mathrm{C}, \mathrm{pH} 7$ and in $3 \mathrm{M} \mathrm{NaCl}$. Moreover, the maximum lipase activity for isolate 1 was explored at $40^{\circ} \mathrm{C}$, $\mathrm{pH} 7.0$ and 2.0-3.5 M NaCl, and for isolate 2 at $35^{\circ} \mathrm{C}, \mathrm{pH} 7.5$ and in $2 \mathrm{M} \mathrm{NaCl}$. Optimal conditions for both extreme halophilic Archaea was determined as the data may be considered for the production of industrial enzymes. Therefore, this research is an exemplary study as well as a small-scoped survey which includes the two goals mentioned above and only focuses on two archaea on salted raw hides.

KEY WORDS: salted hides, halophilic archaea, halophilic esterase, halophilic lipase
\end{abstract}

IDENTIFICAREA FILOGENETICĂ A DOUĂ ARCHAEA EXTREM HALOFILE IZOLATE DIN PIEI CRUDE ŞI INVESTIGAREA ACTIVITĂTILOR LIPOLITICE ALE ACESTORA

REZUMAT. Acest studiu de cercetare are două scopuri distincte. În primul rând, două Archaea extrem halofile au fost izolate din probe de piele crudă şi au fost identificate filogenetic prin analize de secvență ARNr 16S. S-a determinat faptul că izolatul 1 are similitudini cu tulpina Halomicrobium zhouii 144, iar izolatul 2 cu tulpina Haloarchaeon 129. Aceste rezultate au fost confirmate prin câteva analize fenotipice. Ambele tulpini au prezentat reacţii Gram-negative şi au fost sensibile la bacitracină şi novobiocină. S-a determinat calitativ faptul că au activitate lipolitică. În al doilea rând, condiţiile de activitate a esterazei şi lipazei la cele două Archaea au fost determinate în studiul de faţă pentru a evalua aplicabilitatea industrială a acestor enzime. Pentru identificarea activităţilor cantitative ale esterazei şi lipazei la ambele tulpini, s-au utilizat substraturi pe bază de p-nitrofenil butirat, respectiv p-nitrofenil laurat, iar activităţile acestora au fost măsurate zilnic. După determinarea cantitativă şi calitativă a activităţilor esterazei şi lipazei, s-au observat activităţile esterazei şi lipazei la diferite temperaturi $\left(4-60^{\circ} \mathrm{C}\right)$, nivel de $\mathrm{pH}(4-11)$ şi concentraţii de $\mathrm{NaCl}(0-5,5 \mathrm{M})$. Conform rezultatelor activităţii zilnice ale enzimelor, cele mai mari valori ale esterazei şi lipazei pentru izolatul $1 \mathrm{~s}$-au dovedit a fi de $4 \mathrm{U} / \mathrm{ml}$, respectiv $1 \mathrm{U} / \mathrm{ml}$, în cea de-a patra zi, iar pentru izolatul 2 valorile au fost de $2,7 \mathrm{U} / \mathrm{ml}$, respectiv $1,9 \mathrm{U} / \mathrm{ml}$, în cea de-a treia zi. Mai mult, activitatea maximă a esterazei pentru izolatul 1 a avut loc la $35^{\circ} \mathrm{C}, \mathrm{pH} 8$ şi $2,5 \mathrm{M}$ $\mathrm{NaCl}$, iar pentru izolatul 2, la $35^{\circ} \mathrm{C}, \mathrm{pH} 7$ şi $3 \mathrm{M} \mathrm{NaCl}$. Activitatea maximă a lipazei pentru izolatul 1 a avut loc la $40^{\circ} \mathrm{C}, \mathrm{pH} 7,0$ şi $2,0-3,5 \mathrm{M} \mathrm{NaCl}$, iar pentru izolatul 2, la $35^{\circ} \mathrm{C}, \mathrm{pH} 7,5$ şi $2 \mathrm{M} \mathrm{NaCl}$. S-au determinat condiţiile optime pentru ambele Archaea extrem halofile pentru ca datele să poată fi luate în considerare pentru producţia de enzime industriale. Prin urmare, această cercetare este un studiu exemplar cu domeniu de aplicare restrâns, care include cele două obiective menţionate mai sus şi se concentrează doar pe două Archaea izolate din piei brute sărate. CUVINTE CHEIE: piei sărate, Archaea halofile, esterază halofilă, lipază halofilă

\section{L'IDENTIFICATION PHYLOGÉNÉTIQUE DE DEUX ARCHÉES EXTRÊMEMENT HALOPHILES ISOLÉES DE LA PEAU ET L’INVESTIGATION SUR} LEURS ACTIVITÉS LIPOLYTIQUES

RÉSUMÉ. Cette recherche a deux objectifs différents. Principalement, deux archées extrêmement halophiles ont été isolées d'échantillons salés de peau crue et ont été identifiées phylogénétiquement par des analyses de séquences d'ARNr 16S. On a été déterminé que l'isolat 1 partageait des similitudes avec la souche Halomicrobium zhouii 144 et l'isolat 2 avec la souche Haloarchaeon 129. Ces résultats ont été confirmés par certaines analyses phénotypiques. Les deux souches ont présenté des réactions Gram-négatives et ont été sensibles aux antibiotiques bacitracine et novobiocine. On a déterminé qualitativement qu'ils ont une activité lipolytique. Deuxièmement, les conditions d'activité enzymatique de l'esterase et de la lipase des deux archées ont également été déterminées dans l'étude actuelle pour évaluer l'applicabilité industrielle de ces enzymes. Pour l'identification des activités quantitatives de l'estérase et de la lipase des deux souches,

* Correspondence to: Binnur MERIÇLi YAPICI, Department of Biology, Faculty of Arts and Sciences, Çanakkale Onsekiz Mart University, 17020, Çanakkale, Turkey, byapici@comu.edu.tr 
on a utilisé des substrats de p-nitrophényl butyrate et respectivement de p-nitrophényl laurate et leurs activités ont été mesurées quotidiennement. Après la détermination quantitative et qualitative des activités de l'estérase et de la lipase, on a observé les activités de l'esterase et de la lipase à différentes températures $\left(4-60^{\circ} \mathrm{C}\right), \mathrm{pH}(4-11)$ et concentration de $\mathrm{NaCl}(0-5,5 \mathrm{M})$. Selon les résultats quotidiens de l'activité enzymatique, on a trouvé que les valeurs les plus élevées d'estérase et de lipase pour l'isolât 1 ont été $4 \mathrm{U} / \mathrm{ml}$ et $1 \mathrm{U} / \mathrm{ml}$, respectivement, le 4ème jour et pour l'isolât 2 les valeurs ont été 2,7 U/ml et respectivement 1,9 $\mathrm{U} / \mathrm{ml}$, le 3ème jour. De plus, l'activité estérase maximale pour l'isolât 1 a été provoquée à $35^{\circ} \mathrm{C}, \mathrm{pH} 8$ et $2,5 \mathrm{M} \mathrm{NaCl}$, et pour l'isolât 2 , à $35^{\circ} \mathrm{C}, \mathrm{pH} 7$ et $3 \mathrm{M} \mathrm{NaCl}$. L'activité lipase maximale pour l'isolât 1 a été explorée à $40^{\circ} \mathrm{C}, \mathrm{pH} 7,0$ et 2,0-3,5 $\mathrm{M} \mathrm{NaCl}$, et pour l'isolât 2, à $35^{\circ} \mathrm{C}$, pH 7,5 et $2 \mathrm{M} \mathrm{NaCl}$. Les conditions optimales pour les deux archées extrêmement halophiles ont été déterminées car les données peuvent être considérées pour la production d'enzymes industrielles. Par conséquent, cette recherche est une étude exemplaire ainsi qu'une enquête à petite échelle qui comprend les deux objectifs mentionnés ci-dessus et se concentre uniquement sur deux archées sur les peaux crues salées.

MOTS CLÉS: peaux salées, archées halophile, esterase halophile, lipase halophile

\section{INTRODUCTION}

The primary raw materials of the leather industry are hides and skins [1]. Autolytic destruction starts after 5-6 hours following the flaying if they are not well protected [26]. Therefore, raw hides or skins should be conserved with salt before transferred to tannery for processing [7-9]. Although this method limits the microbial growth, it does not provide sufficient protection [10, 11]. Halophiles, which need a high amount of salt concentration to live in and have developed different strategies with this property to survive in salt-loving environment, are members of a large group and have representatives in all three domains known as Bacteria, Archaea and Eukaryotes [12]. Halophiles were classified by Kushner [13] according to their need for optimal amount of $\mathrm{NaCl}$.

In leather industry, microbiological research is scarce. Most studies are related to bacteria and fungi. But in recent years, attention is drawn to the presence of Archaea in raw hides. Different types of halophilic archaea with hydrolytic activity have been identified on salted raw hides and skins. For example, in the study by Bilgi et al. [14], 186 extremely halophilic archaea, which need $15 \%$ or higher salt were shown to exhibit proteolytic (107 strains) and lipolytic (70 strains) activity, were isolated from salted skins or hides.

Furthermore, industrial enzymes are usually obtained from microorganisms. The comparison between microbial enzymes and other enzymes originating from plants or animals revealed that microbial enzymes have high catalytic activities, do not generate undesirable by-products, are more stable and inexpensive, and can be obtained in large quantities [15]. Many studies in the field related to industrial enzymes of biotechnology are being

\section{INTRODUCERE}

Principala materie primă a industriei de pielărie este pielea de origine animală [1]. Distrugerea autolitică a acesteia începe după 5-6 ore de la jupuire în cazul în care pieile nu sunt bine protejate [2-6]. Prin urmare, pieile crude necesită conservare cu sare înainte de a fi transferate la tăbăcărie pentru prelucrare [7-9]. Această metodă limitează creşterea microbiană, însă nu oferă o protecţie suficientă $[10,11]$. Halofilele, care au nevoie de o cantitate mare de sare pentru a supraviețui și au dezvoltat diferite strategii pe baza acestei proprietăţi pentru a supravieţui într-un mediu sărat, fac parte dintr-o grupă mare şi au reprezentanţi în toate cele trei domenii cunoscute sub numele de Bacteria, Archaea şi Eucaria [12]. Halofilele au fost clasificate de către Kushner [13] în funcţie de nevoia lor de cantitate optimă de $\mathrm{NaCl}$.

În industria de pielărie, cercetarea microbiologică este limitată. Cele mai multe dintre studii se concentrează pe bacterii şi fungi. Însă în ultimii ani, atenţia s-a îndreptat asupra prezenţei Archaea pe piei brute. Diferite tipuri de Archaea halofile cu activitate hidrolitică au fost identificate pe piei brute sărate. De exemplu, în studiul efectuat de Bilgi şi colab. [14], s-a dovedit că 186 Archaea extrem halofile, care au nevoie de sare în concentraţie de $15 \%$ sau mai mult, prezintă activitate proteolitică (107 tulpini) şi lipolitică (70 tulpini) și au fost izolate din piei sărate.

De asemenea, enzimele industriale sunt de obicei obţinute din microorganisme. Comparaţia dintre enzimele microbiene şi alte enzime de origine vegetală sau animală a arătat că enzimele microbiene au activităţi catalitice ridicate, nu generează produse secundare indezirabile, sunt mai stabile şi ieftine şi pot fi obţinute în cantităţi mari [15]. Multor studii referitoare la enzimele industriale din domeniul biotehnologiei li se 
attached more importance due to the gradual development of enzyme technology, diversified usages and very high economic value of the products. Lipases are widely used in fields such as clinical biotechnology, detergent industry, biodiesel production, taste and flavor industry and food industry. Lipase enzyme can also be used in the leather industry to prepare pelts for processes such as tanning and dyeing by removing skin fats [16]. In literature, there is little research on the examination of lipase from extremely halophilic archaea on the leather. Therefore, investigation of the lipase enzyme obtained from different microorganisms such as archaea and determination of the activity conditions are of great importance.

Leather processing steps are home to a wide variety of microorganisms classified into the three domains of life such as Bacteria, Archaea and Eukaryotes. Therefore, identification of the microbial diversity and their products in these environments can make significant contributions to the humanity, which cannot be predicted in advance.

In this study, only two of the Extremely Halophilic Archaea, which have lipolytic activity and are able to survive on salted raw hides were phylogenetically identified by $16 \mathrm{~S}$ rRNA gene sequence analyses. Additionally, lipolytic activities of archaea were investigated in different environmental conditions such as temperature, $\mathrm{pH}$ value and salt content.

\section{MATERIAL AND METHODS}

Two lipolytic halophilic Archaea isolates which were previously isolated from salted raw hides were used in the present research. SW 25 medium was used for culture isolation, activation and phenotypic tests. This medium was composed of $833.4 \mathrm{ml} / \mathrm{l} \mathrm{SW} 30$ solution, 5 $\mathrm{g} / \mathrm{l}$ yeast extract, and $20 \mathrm{~g} / \mathrm{l}$ agar. SW 30 solution contains $234 \mathrm{~g} / \mathrm{l} \mathrm{NaCl}, 39 \mathrm{~g} / \mathrm{l} \mathrm{MgCl}{ }^{\prime}, 61 \mathrm{~g} / \mathrm{I} \mathrm{MgSO}_{4^{\prime}}$ $1 \mathrm{~g} / \mathrm{l} \mathrm{CaCl}{ }_{2}, 6 \mathrm{~g} / \mathrm{l} \mathrm{KCl}, 0.25 \mathrm{~g} / \mathrm{l} \mathrm{NaHCO}$, and 0.7 $\mathrm{g} / \mathrm{I} \mathrm{NaBr}$. Media were adjusted to $\mathrm{pH} 7.5$ with $1 \mathrm{~N} \mathrm{NaOH}$ [17]. Dussault [18] Gram staining was performed for determination of Gram reactions and of cell morphology of the isolates. To test antibiotic susceptibilities of the isolates, disc diffusion method was applied and antibiotics such as Ampicillin $10 \mu \mathrm{g}$ (A 10), Bacitracin $10 \mu \mathrm{g}$ (B 10), Erythromycin $15 \mu \mathrm{g}$ (E 15), Novobiosin $30 \mu \mathrm{g}$ acordă o importanţă mai mare datorită dezvoltării treptate a tehnologiei enzimatice, utilizărilor diversificate şi valorii economice foarte ridicate a produselor. Lipazele sunt utilizate pe scară largă în domenii cum ar fi biotehnologia clinică, industria detergenţilor, producţia de biodiesel, industria aromelor şi industria alimentară. Lipaza poate fi, de asemenea, utilizată în industria de pielărie la pregătirea pieilor gelatină pentru procese precum tăbăcirea şi vopsirea prin îndepărtarea grăsimilor pielii [16]. În literatura de specialitate, există puţine cercetări privind examinarea lipazei din Archaea extrem halofile din piele. Prin urmare, investigarea lipazei obţinute din diferite microorganisme, cum ar fi Archaea, şi determinarea condiţiilor de activitate ale acesteia sunt foarte importante.

Etapele de prelucrare a pielii favorizează apariția unei mari varietăţi de microorganisme clasificate în cele trei domenii ale vieţii, şi anume Bacteria, Archaea și Eucaria. Prin urmare, identificarea diversităţii microbiene şi a produselor rezultate în aceste medii poate aduce contribuţii semnificative umanității, care nu pot fi prezise în avans.

În acest studiu s-au identificat filogenetic prin analize de secvenţă a genei ARNr 16S doar două dintre Archaea extrem halofile, care au activitate lipolitică şi sunt capabile să supravieţuiască pe pieile crude sărate. În plus, activităţile lipolitice ale Archaea au fost investigate în diferite condiţii de mediu, cum ar fi temperatura, valoarea $\mathrm{pH}$-ului şi conţinutul de sare.

\section{MATERIAL ŞI METODE}

În cadrul prezentei cercetări s-au utilizat două izolate Archaea halofile lipolitice care au fost izolate anterior din piei brute sărate. Mediul SW 25 a fost utilizat pentru testele de izolare a culturii, de activare şi fenotipice. Acest mediu a fost compus din $833,4 \mathrm{ml} / \mathrm{l} \mathrm{SW} 30$ soluţie, 5 $\mathrm{g} / \mathrm{l}$ extract de drojdie şi $20 \mathrm{~g} / \mathrm{l}$ agar. Soluţia SW 30 conţine $234 \mathrm{~g} / \mathrm{l} \mathrm{NaCl}, 39 \mathrm{~g} / \mathrm{l} \mathrm{MgCl}, 61 \mathrm{~g} / \mathrm{l}$ $\mathrm{MgSO}_{4^{\prime}} 1 \mathrm{~g} / \mathrm{l} \mathrm{CaCl}, 6 \mathrm{~g} / \mathrm{l} \mathrm{KCl}, 0,25 \mathrm{~g} / \mathrm{l} \mathrm{NaHCO}_{3^{\prime}}$, şi $0,7 \mathrm{~g} / \mathrm{I} \mathrm{NaBr}$. S-a ajustat $\mathrm{pH}$-ul mediilor la 7,5 cu NaOH $1 \mathrm{~N}$ [17]. S-a efectuat colorația Gram Dussault [18] pentru a determina reacţiile Gram şi morfologia celulară a izolatelor. Pentru a testa sensibilitatea izolatelor la antibiotice, s-a aplicat metoda de difuziune a discurilor și s-au utilizat 
(NV 30), Penicillin G 10 U (P 10), Streptomycin 10 $\mu \mathrm{g}$ (S 10), Tetracycline $30 \mu \mathrm{g}$ (T 30), Vancomycin $30 \mu \mathrm{g}$ (VAN 30), Chloramphenicol $30 \mu \mathrm{g}$ (C 30), and Cefotaxime $30 \mu \mathrm{g}$ (CTX 30) were used [1921].

The genomic DNA isolation of two Archaea isolates was performed by using the modified version of the Dyall-Smith [22] method and Geneon ${ }^{\circledR}$ Bacterial DNA isolation kit. For Genomic DNA isolation, $1.5 \mathrm{ml}$ of the culture samples $\left(\mathrm{OD}_{600 \sim} 1\right)$ grown in SW-25 liquid medium was transferred into sterile microcentrifuge tubes and centrifuged at $+4^{\circ} \mathrm{C}$ at $10.000 \times$ for $10 \mathrm{~min}$. After removing the supernatants of the samples, $400 \mu \mathrm{l}$ of sterile cold ultra-pure water was added in the tubes and the resultant mixture was shaken for a short time to disintegrate the cells. Samples were centrifuged at $+4^{\circ} \mathrm{C}, 10.000 \times \mathrm{xg}$ for $3 \mathrm{~min}$ to remove supernatants, and genomic DNA isolation was performed in line with the instructions of the commercial kit. $0.8 \%$ agarose gel ( $80 \mathrm{~V}, 100 \mathrm{~mA}, 1$ hour) was prepared with $1 \mathrm{X}$ TAE for control and Syber ${ }^{\circledR}$ Green I and $6 \mathrm{X}$ gel loading dye was used to load the samples onto the gel.

The distinction between Archaea and Bacteria was made by 165 rRNA molecular Polymerase Chain Reaction (PCR) with used bac27f/bac1492r and arc7f/arc1384r primers $[23,24]$. For the configuration of Polymerase Chain Reaction (PCR), Geneon ${ }^{\circledR}$ Maximo TaqDNA Polymerase kit was used. This PCR program consisted of 30 repetitive cycles with a strand separation step at $94^{\circ} \mathrm{C}$ for $45 \mathrm{~s}$, an annealing step at $53^{\circ} \mathrm{C}$ of $45 \mathrm{~s}$, and an elongation step for $1 \mathrm{~m}$ at $72^{\circ} \mathrm{C}$. PCR samples were made to move forward on $1.7 \%$ agarose gel to check. Haloferax sp. HSC4 was used for Archaea and Salinibacter ruber for Bacteria for a positive control. Chromatograms of the sequence analyses were viewed and edited via Chromas ${ }^{\circledR}$. Forward and reverse sequences were aligned on the NCBI's (National Center of Biotechnology Information) website, and then 16S rRNA gene sequences were obtained by removing the shared parts. These sequences were analyzed by using nucleotide BLAST (Basic Local Alignment Search Tool) at http://www. ncbi.nlm.nih.gov and compared with existing $16 \mathrm{~S}$ rRNA sequences in the GenBank database. antibiotice cum ar fi: ampicilină $10 \mu \mathrm{g}$ (A 10), bacitracină $10 \mu \mathrm{g}(\mathrm{B} 10)$, eritromicină $15 \mu \mathrm{g}(\mathrm{E}$ 15), novobiocină $30 \mu \mathrm{g}$ (NV 30), penicilină G 10 U (P 10), streptomicină $10 \mu \mathrm{g}(\mathrm{S} 10)$, tetraciclină $30 \mu \mathrm{g}$ ( $\mathrm{T}$ 30), vancomicină $30 \mu \mathrm{g}$ (VAN 30), cloramfenicol $30 \mu \mathrm{g}$ (C 30), cefotaxim $30 \mu \mathrm{g}$ (CTX 30) [19-21].

S-a izolat ADN-ul genomic din două izolate Archaea utilizând versiunea modificată a metodei Dyall-Smith [22] şi kitul de izolare a ADN-ului bacterian Geneon ${ }^{\circledR}$. Pentru izolarea ADN-ului genomic, s-a transferat $1,5 \mathrm{ml}$ din probele de cultură $\left(O_{600 \sim} 1\right)$ cultivate în mediu lichid SW25 în tuburi de microcentrifugare sterile şi s-au centrifugat la $+4^{\circ} \mathrm{C}$ la $10,000 \times$ g timp de $10 \mathrm{~min}$. După îndepărtarea supernatanţilor probelor, s-au adăugat $400 \mu \mathrm{l}$ de apă rece sterilă ultra-pură în tuburi, iar amestecul rezultat a fost agitat timp de o perioadă scurtă pentru a dezintegra celulele. Probele au fost centrifugate la $+4^{\circ} \mathrm{C}, 10,000 \mathrm{xg}$ timp de 3 min, pentru a îndepărta supernatanţii, iar izolarea ADN-ului genomic a fost realizată în conformitate $\mathrm{cu}$ instrucţiunile kitului comercial. S-a preparat $0,8 \%$ gel de agaroză $(80 \mathrm{~V}, 100 \mathrm{~mA}$, 1 oră), având ca martor $1 \mathrm{X}$ TAE, folosind Syber ${ }^{\circledR}$ Green I şi 6X colorant de încărcare în gel pentru a încărca probele pe gel.

Distincţia dintre Archaea şi bacterii s-a realizat prin reacția de polimerizare în lanț (PCR) molecularăa ARNr 16Scu primeribac27f/bac1492r şi $\operatorname{arc7f} / \operatorname{arc1384r}[23,24]$. Pentru configurarea reacției de polimerizare în lanț (PCR), s-a folosit kitul Geneon ${ }^{\circledR}$ Maximo TaqDNA Polymerase. Acest program PCR a constat din 30 de cicluri repetitive cu o etapă de separare a fibrelor la $94^{\circ} \mathrm{C}$ timp de $45 \mathrm{~s}$, o etapă de maleabilizare la $53^{\circ} \mathrm{C}$ timp de 45 $\mathrm{s}$, şi o etapă de alungire de $1 \mathrm{~m} \mathrm{la} 72^{\circ} \mathrm{C}$. Probele PCR au fost verificate prin migrare în $1,7 \%$ gel de agaroză. S-a utilizat Haloferax sp. HSC4 ca martor pozitiv pentru Archaea şi Salinibacter ruber ca martor pozitiv pentru bacterii. Cromatogramele analizelor de secvenţă au fost vizualizate şi editate utilizând programul Chromas ${ }^{\circledR}$. Secvenţele directe și inverse au fost comparate cu cele regăsite pe site-ul NCBI (Centrul Naţional de Informare în Biotehnologii), şi apoi s-au obţinut secvenţele genei ARNr $16 \mathrm{~S}$ prin îndepărtarea părților comune. Aceste secvenţe au fost analizate cu ajutorul programului Nucleotide BLAST (Basic Local Alignment Search Tool) disponibil la http:// www.ncbi.nlm.nih.gov şi s-au comparat cu 
Esterase test [25-27] and lipase test [28, 26] were applied in screening qualitatively extracellular hydrolytic enzyme. Inoculated isolates were incubated for 7 days at $37^{\circ} \mathrm{C}$ on SW25 agar containing $1 \%$ Tween 80 . Opaque zone observed around the colony was considered as positive esterase activity [25-27]. For lipase activity, inoculated isolates were incubated for 7 days at $37^{\circ} \mathrm{C}$ on modified rhodamine $\mathrm{B}$ lipase agar. After the incubation, plates were examined under $350 \mathrm{~nm}$ ultraviolet (UV) light. Bright orange-red colonies were evaluated as positive lipase activity [26, 28, 29].

After the isolates were cultured in SW25 broth medium at $37^{\circ} \mathrm{C}$ at $150 \mathrm{rpm}$, the liquid samples were taken daily. $1 \%$ Tween 80 and olive oil were added to medium as inducing agent. The samples were centrifuged at $10.000 x g$ for $10 \mathrm{~min}$ and then supernatants were used as the enzyme source. Esterase and lipase activities were measured at $410 \mathrm{~nm}$ of UV spectrophotometer using $p$-Nitrophenyl butyrate (pNPB) and p-nitrophenyl laurate (pNPL), respectively [30]. Both of $10 \mathrm{mM}$ pNPB and PNPL were dissolved in 2-propanol for substrate solution. Buffer solution was prepared in pure water and meanwhile 100 $\mathrm{mM}$ Tris $\mathrm{HCl}, 0.5 \%$ Triton $\mathrm{X}-100,2 \mathrm{M} \mathrm{NaCl}$ at $\mathrm{pH}$ 7.5 were added. Substrate mixture was prepared by adding $1 \mathrm{ml}$ substrate solution into $9 \mathrm{ml}$ buffer solution $(1: 9, v / v)$ and preheating was carried out at $37^{\circ} \mathrm{C}$ for 5 minutes. The solution was freshly prepared each time.

Firstly, reactions of esterase and lipase activity were performed with $0.8 \mathrm{ml}$ of pNP substrate mixture and $0.2 \mathrm{ml}$ of enzyme source for $10 \mathrm{~min}$ at $37^{\circ} \mathrm{C}$. Secondly, $0.5 \mathrm{ml}$ of $\mathrm{Na}_{2} \mathrm{CO}_{3}$ $(0.5 \mathrm{M})$ was used as reaction stopper and finally the samples were centrifuged at $10.000 \times \mathrm{g}$ for $10 \mathrm{~min}$. The same procedure was applied for the blind tube without the enzyme source. The enzyme amount producing $1 \mu \mathrm{mol}$ p-Nitrophenol per minute under aforementioned reaction conditions was identified as the 1 unit of milliliter $(\mathrm{U} / \mathrm{ml})$ enzyme activity [30, 31]. Different temperatures $\left(4-60^{\circ} \mathrm{C}\right), \mathrm{pH}(3.0-12.0 \mathrm{pH})$ and $\mathrm{NaCl}$ (0.5-5M) conditions were modified in reactions to determine their effects on enzyme activities. In acidic reactions, sodium acetate buffer was used instead of Tris $\mathrm{HCl}$ buffer. secvenţele ARNr $16 S$ existente din baza de date GenBank.

S-au efectuat testul esterazei [25-27] şi testul lipazei $[28,26]$ pentru selectarea enzimei hidrolitice extracelulare calitative. Izolatele inoculate au fost incubate timp de 7 zile la temperatura de $37^{\circ} \mathrm{C}$ pe agar SW-25 conţinând 1\% Tween 80. Zona opacă observată în jurul coloniei a fost considerată activitate pozitivă a esterazei [25-27]. Pentru activitatea lipazei, izolatele inoculate au fost incubate timp de 7 zile la $37^{\circ} \mathrm{C}$ pe agar modificat cu rodamina B. După incubare, plăcile au fost examinate la lumină ultravioletă (UV) de $350 \mathrm{~nm}$. Coloniile roşuportocaliu aprins au reprezentat o activitate pozitivă a lipazei $[26,28,29]$.

După cultivarea izolatelor în mediu SW25 la $37^{\circ} \mathrm{C}$ la $150 \mathrm{rpm}$, s-au prelevat zilnic probe de lichid. S-au adăugat în mediu 1\% Tween 80 şi ulei de măsline ca agenţi de inducere. Probele au fost centrifugate la $10,000 \times$ timp de 10 minute şi apoi s-au utilizat supernatanții ca sursă de enzimă. Activităţile esterazei şi lipazei au fost măsurate la $410 \mathrm{~nm}$ cu spectrofotometrul UV, utilizând $p$-nitrofenil butirat (pNPB), respectiv laurat de $p$-nitrofenil (pNPL) [30]. S-au dizolvat câte $10 \mathrm{mM}$ de pNPB şi pNPL în 2-propanol ca soluţie substrat. Soluţia tampon a fost preparată în apă pură şi s-au adăugat $100 \mathrm{mM}$ Tris $\mathrm{HCl}$, 0,5\% Triton X-100, $2 \mathrm{M} \mathrm{NaCl}$ la pH 7,5. Amestecul de substrat a fost preparat prin adăugarea a $1 \mathrm{ml}$ soluţie substrat în $9 \mathrm{ml}$ de soluţie tampon (1:9, v/v) şi s-a preîncălzit la $37^{\circ} \mathrm{C}$ timp de 5 minute. Soluţia a fost preparată proaspăt de fiecare dată.

În primul rând, reacţiile esterazei şi lipazei au fost efectuate cu $0,8 \mathrm{ml}$ amestec de substrat pNP şi $0,2 \mathrm{ml}$ sursă de enzimă timp de 10 minute la $37^{\circ} \mathrm{C}$. În al doilea rând, s-a utilizat $0,5 \mathrm{ml}$ de $\mathrm{Na}_{2} \mathrm{CO}_{3}(0,5 \mathrm{M})$ pentru a inhiba reacţia şi în final, probele au fost centrifugate la $10,000 \times \mathrm{g}$ timp de $10 \mathrm{~min}$. S-a aplicat aceeaşi procedură pentru tubul martor fără sursă de enzimă. Cantitatea de enzimă care produce $1 \mu \mathrm{mol}$ p-nitrofenol pe minut în condiţiile de reacţie menţionate mai sus a fost identificată ca fiind 1 unitate de mililitru $(\mathrm{U} / \mathrm{ml})$ activitate enzimatică $[30,31]$. S-au variat temperaturile $\left(4-60^{\circ} \mathrm{C}\right), \mathrm{pH}-\mathrm{ul}(3,0-12,0 \mathrm{pH})$ şi $\mathrm{NaCl}(0,5-5 \mathrm{M})$ în reacţii pentru a determina efectele acestor factori asupra activităţilor enzimatice. În reacţiile acide, s-a utilizat ca tampon acetat de sodiu în loc de Tris $\mathrm{HCl}$. 


\section{RESULTS AND DISCUSSION}

Gram stain, antibiotic susceptibility testing and 16S rRNA sequence analysis method were applied to isolates. Then, their hydrolytic enzyme activities were determined qualitatively and quantitatively. Esterase and lipase activities of isolates were also determined quantitatively according to qualitative findings. In the meantime, the effects of enzyme amount, temperature, $\mathrm{pH}$ and salt variables on esterase and lipase activities were measured spectrophotometrically.

\section{Morphological and Microscopic Characteristics of the Isolates}

Both isolates used in the current research were observed with the cream colored colonies on SW 25 agar after 7 days incubation at $37^{\circ} \mathrm{C}$. Both of isolates have been found to be rod shape and Gram negative [Gr (-)](Figure 1).

\section{REZULTATE Şı DISCUTII}

S-au aplicat coloraţia Gram, testarea sensibilităţii la antibiotice şi metoda de analiză a secvenţei ARNr 16S. Apoi s-au determinat calitativ şi cantitativ activităţile enzimatice hidrolitice. Activităţile esterazei şi lipazei din izolate au fost, de asemenea, determinate cantitativ conform constatărilor calitative. Între timp, s-au măsurat spectrofotometric efectele cantităţii de enzimă, temperaturii, pH-ului şi cantității variabile de sare asupra activităţilor esterazei şi lipazei.

\section{Caracteristici morfologice şi microscopice ale izolatelor}

În cazul ambelor izolate folosite în cercetările de față s-au observat colonii de culoare crem pe agar SW 25 după 7 zile de la incubare la temperatura de $37^{\circ} \mathrm{C}$. Ambele izolate au avut formă de tijă şi colorație Gram negativă [Gr (-)] (Figura 1).
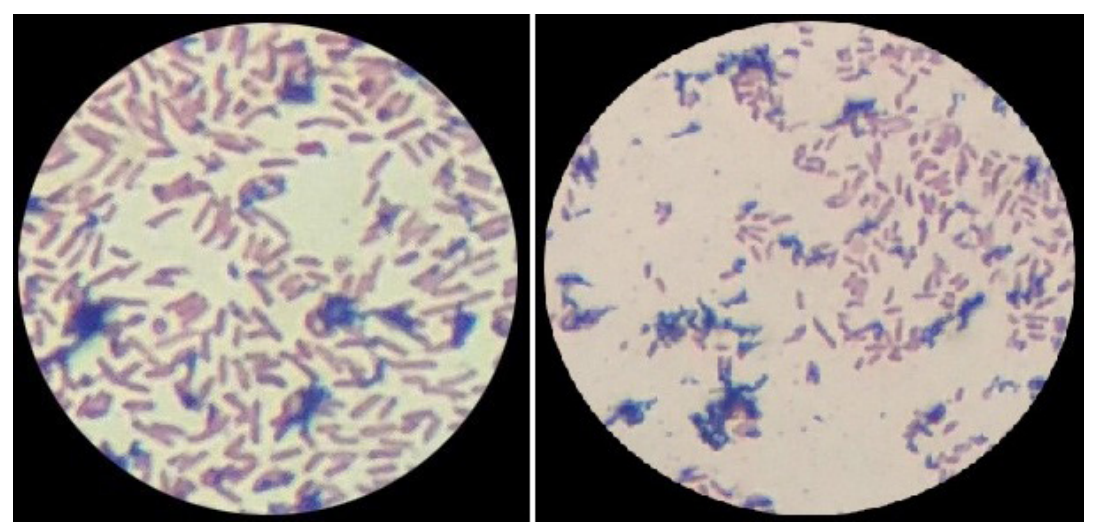

Figure 1. Gram stain images of isolate 1 (left) and isolate 2 (right)

Figura 1. Imagini cu coloraţie Gram ale izolatului 1 (stânga) şi izolatului 2 (dreapta)

\section{Distinction between Bacteria and Archaea}

According to the findings of antibiotic susceptibility test, both isolates were sensitive to bacitracin and novobiocin antibiotics, while they were resistant to other antibiotics used in the study. Holmes and Dyall-Smith [32] expressed that most halophilic Archaea are susceptible to novobiocin and bacitracin, which are DNA gyrase inhibitors. Çetinkuş [33] identified the isolated halophilic microorganisms as Archaea or Bacteria via 16S rRNA analysis and found that the isolates were susceptible to bacitracin and novobiocin and resistant to penicillin G. Yıldız et al. [34] reported that halophilic Archaea isolates were gram-negative and gram-variable features and were sensitive to novobiocin and bacitracin antibiotics in their study.

\section{Distincţia dintre Bacteria şi Archaea}

Conform rezultatelor testului de sensibilitate la antibiotice, ambele izolate au fost sensibile la bacitracină şi novobiocină şi rezistente la alte antibiotice utilizate în studiu. Holmes şi Dyall-Smith [32] au afirmat că majoritatea Archaea halofile sunt sensibile la novobiocină şi bacitracină, care sunt inhibitori ai girazei ADN. Çetinkuş [33] a identificat microorganismele halofile izolate ca Archaea sau bacterii prin analiza ARNr $16 \mathrm{~S}$ şi a constatat că tulpinile au prezentat sensibilitate la bacitracină şi novobiocină şi rezistenţă la penicilina G. Yıldız şi colab. [34] au raportat în studiul lor că izolatele Archaea halofile sunt gram-negative şi gramvariabile şi prezintă sensibilitate la novobiocină şi bacitracină. 
In this study, the features of isolate 1 and 2 have been found to be similar to the general characteristics of the domain Archaea. The findings of the present and previous studies indicate that the isolates might be Archaea. The results of PCR performed with Archaea and Bacteria primers disclosed that isolate 1 and 2 belong to the Archaea domain (Figure 2).
În acest studiu, caracteristicile izolatelor 1 şi 2 s-au dovedit a fi similare cu caracteristicile generale ale domeniului Archaea. Constatările studiilor anterioare şi actuale indică faptul că izolatele ar putea face parte din domeniul Archaea. Rezultatele tehnicii PCR efectuate cu primeri Archaea şi Bacteria au arătat că izolatele 1 şi 2 aparţin domeniului Archaea (Figura 2).

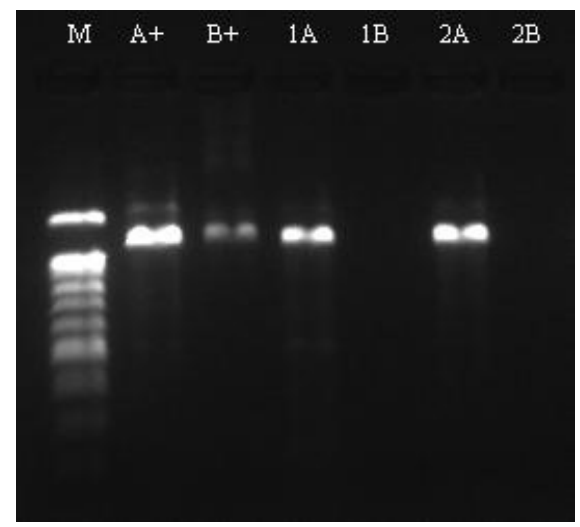

Figure 2. Agarose gel image of PCR products of isolates. M: Marker, A +: Archaea positive control, B +: Bacterial positive control, 1A: isolates 1 with Archaea primers, 1B: isolates 1 with Bacteria Primer, 2A: isolates 2 with Archaea Primer, 2B: isolate 2 with Bacteria Primer

Figura 2. Imaginea obţinută cu ajutorul gelului de agaroză a produselor PCR ale izolatelor. M: marker, A+: martor pozitiv Archaea, B+: martor pozitiv bacterian, 1A: izolate $1 \mathrm{cu}$ primeri Archaea, 1B: izolate $1 \mathrm{cu}$ primeri bacterii, 2A: izolate 2 cu primeri Archaea, 2B: izolate 2 cu primeri bacterii

In our study, 16S rRNA sequence analysis method was used for molecular diagnostics of isolate 1 and 2 . As a result, it was found that isolate 1 was similar to Halomicrobium zhouii strain 144 and isolate 2 was similar to Haloarchaeon strain 129 according to the gene bank database. 16S rRNA gene sequences of Halomicrobium zhouii strain 144 and Haloarchaeon strain 129 were determined by Bilgi et al. [14] In their study, Haloarchaeon strain 129 was isolated from salted raw hide and cultivated for the first time. Considering first identified regions for these strains, Halomicrobium zhouii [35] and uncultured haloarchaeon clone YA32 [36] were determined in Jiangsu sea saltern (China). Our findings were found to support the haloarchaeal diversity noted in previous studies.

\section{Qualitative Findings of Hydrolytic Enzyme Activity}

In the present research, esterase and lipase enzyme activities were investigated. Tween-80 for esterase activity and $1 \%$ olive oil for lipase activity were used in enzyme activation. In experiments of quantitative enzyme activity,
În studiul nostru, metoda analizei de secvenţă ARNr $16 \mathrm{~S}$ a fost utilizată pentru diagnostic molecular al izolatelor 1 şi 2 . Ca urmare, s-a constatat că izolatul 1 este similar cu tulpina Halomicrobium zhouii 144, iar izolatul 2 a fost similar cu tulpina Haloarchaeon 129 conform bazei de date a băncii de gene. Secvenţele de gene ARNr $16 \mathrm{~S}$ ale tulpinii Halomicrobium zhouii 144 şi ale tulpinii Haloarchaeon 129 au fost determinate de Bilgi şi colab. [14]. În studiul acestora, tulpina Haloarchaeon 129 a fost izolată din piele crudă sărată şi cultivată pentru prima dată. Luând în considerare mai întâi regiunile identificate pentru aceste tulpini, Halomicrobium zhouii [35] şi clona Haloarchaeon YA32 necultivată [36] au fost determinate în salina Jiangsu (China). Descoperirile noastre au sprijinit diversitatea haloarchaea observată în studiile anterioare.

\section{Rezultate calitative ale activităţii enzimei hidrolitice}

În cercetarea de faţă, s-au investigat activităţile enzimatice ale lipazei şi esterazei. Pentru activarea enzimei s-au utilizat Tween-80 
p-NPB (for esterase test) and p-NPL (for lipase) substrates were used according to the procedure in experimental. Camacho et al. [30] produced esterase and lipase from Haloarcula marismortui and then have carried out their characterization. The researchers declared that p-nitrophenyl butyrate (pNPB), $p$-nitrophenyl valerate (pNPV) for esterase activity and p-nitrophenyl laurate ( $p N P L)$ for lipase activity were used as substrates.

Esterase and lipase activities were measured quantitatively for 10 days. Growth curve was generated for each isolate and the results were compared with activity findings. According to the research findings, the highest esterase $(4 \mathrm{U} / \mathrm{ml})$, and lipase $(1 \mathrm{U} / \mathrm{ml})$ activity values of isolate 1 was determined in supernatant on the $4^{\text {th }}$ day of growth. The highest esterase $(2.7 \mathrm{U} / \mathrm{ml})$ and lipase $(1.9 \mathrm{U} / \mathrm{ml})$ activity values of isolate 2 were determined in supernatant on the $3^{\text {rd }}$ day of growth. These supernatants were used as raw enzyme source in the subsequent enzyme analyses. Enzyme amount was detected as $0.2 \mathrm{ml}$ for the highest esterase activity of both isolates. In such conditions, esterase activity of isolate 1 and 2 were found to be $0.45 \mathrm{U} / \mathrm{ml}$ and $0.54 \mathrm{U} / \mathrm{ml}$, respectively. Optimal temperature was determined as $35^{\circ} \mathrm{C}$ for the highest esterase activity of both isolates. Esterase activity was determined at a wide temperature range of $4-55^{\circ} \mathrm{C}$ (Figure 3). This finding was considered as an important result for industrial esterase production. pentru activitatea esterazei şi ulei de măsline 1\% pentru activitatea lipazei. În experimentele de activitate enzimatică cantitativă, s-au utilizat substraturile p-NPB (pentru testul esterazei) şi p-NPL (pentru testul lipazei), în conformitate cu procedura menționată în partea experimentală. Camacho şi colab. [30] au produs esteraza şi lipaza din Haloarcula marismortui şi apoi le-au caracterizat. Cercetătorii au raportat utilizarea substanțelor $p$-nitrofenil butirat (pNPB) și valerat de $p$-nitrofenil (pNPV) ca substraturi pentru activitatea esterazei şi laurat $p$-nitrofenil (pNPL) ca substrat pentru activitatea lipazei.

Activităţile esterazei şi lipazei au fost măsurate cantitativ timp de 10 zile. S-a generat curba de creştere pentru fiecare izolat, iar rezultatele au fost comparate cu rezultatele activităţii. Conform rezultatelor cercetării, cele mai mari valori ale activităţii esterazei $(4 \mathrm{U} / \mathrm{ml})$ şi lipazei $(1 \mathrm{U} / \mathrm{ml})$ pentru izolatul 1 au fost determinate în supernatant în patra zi de creştere. Cele mai mari valori ale activităţii esterazei $(2,7 \mathrm{U} / \mathrm{ml})$ şi lipazei $(1,9 \mathrm{U} / \mathrm{ml})$ pentru izolatul 2 au fost determinate în supernatant în treia zi de creştere. Aceşti supernatanţi au fost utilizaţi ca sursă primară de enzimă în analizele enzimatice ulterioare. S-a detectat cantitatea de enzimă la $0,2 \mathrm{ml}$ pentru cea mai mare activitate a esterazei din ambele izolate. În aceste condiţii, activitatea esterazei a izolatelor 1 şi $2 \mathrm{~s}$-a dovedit a fi de 0,45 U/ml, respectiv $0,54 \mathrm{U} / \mathrm{ml}$. Temperatura optimă a fost determinată la $35^{\circ} \mathrm{C}$ pentru cea mai mare activitate a esterazei din ambele izolate. Activitatea esterazei a fost determinată în cadrul unei game largi de temperaturi, $4-55^{\circ} \mathrm{C}$ (Figura 3). Această constatare a fost considerată un rezultat important pentru producţia industrială de esterază.

\section{Esterase}

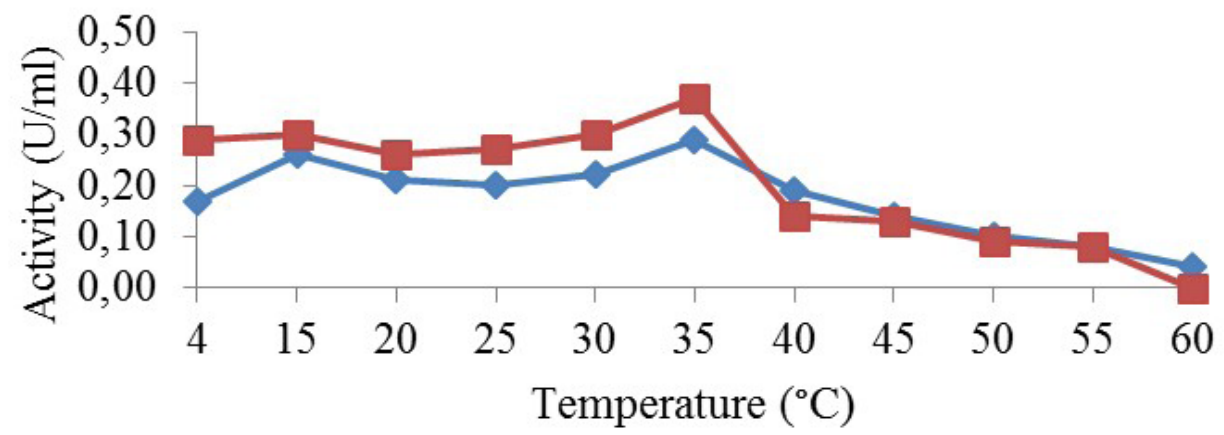

$\leadsto$-Isolate $1 \rightarrow$-Isolate 2

Figure 3. The graph of temperature changes of esterase activity

Figura 3. Graficul modificărilor de temperatură ale activităţii esterazei 
The highest activity of lipase was detected at $40^{\circ} \mathrm{C}$ for isolate 1 and at $35^{\circ} \mathrm{C}$ for isolate 2 . Lipase activity of isolate 2 was observed to be higher than that of isolate 1 (Figure 4).
Cea mai mare activitate a lipazei a fost detectată la $40^{\circ} \mathrm{C}$ pentru izolatul 1 şi la $35^{\circ} \mathrm{C}$ pentru izolatul 2. S-a observat că activitatea lipazei în cazul izolatului 2 este mai mare decât cea a izolatului 1 (Figura 4).

Lipase

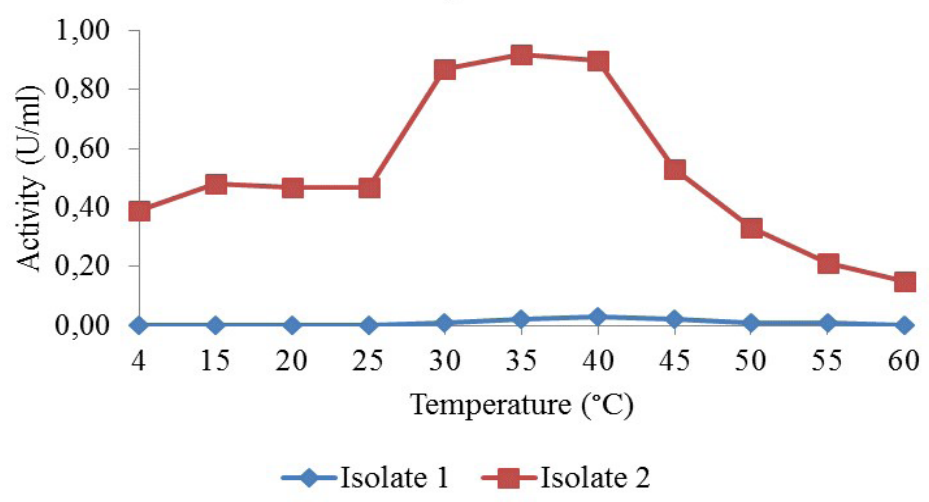

Figure 4. The graph of temperature changes of lipase activity

Figura 4. Graficul modificărilor de temperatură ale activităţii lipazei

The highest activity of esterase was detected at $\mathrm{pH} 8$ for isolate 1 and at $\mathrm{pH} 7$ for isolate 2. It was observed that isolate 2 was active at $\mathrm{pH} 4.5-9$ range, while isolate 1 was active at $\mathrm{pH}$ 6.5-9.5 range. According to the obtained data, it was determined that isolate 2 had esterase activity in more acidic conditions than isolate 1 did (Figure 5).
Cea mai mare activitate a esterazei a fost detectată la pH 8 pentru izolatul 1 şi la pH 7 pentru izolatul 2. S-a observat că izolatul 2 a fost activ în intervalul de $\mathrm{pH} 4,5-9$, iar izolatul 1 a fost activ în intervalul de pH 6,5-9,5. Conform datelor obţinute, s-a constatat că la izolatul 2 activitatea esterazei a avut loc în condiţii mai acide decât în cazul izolatului 1 (Figura 5).

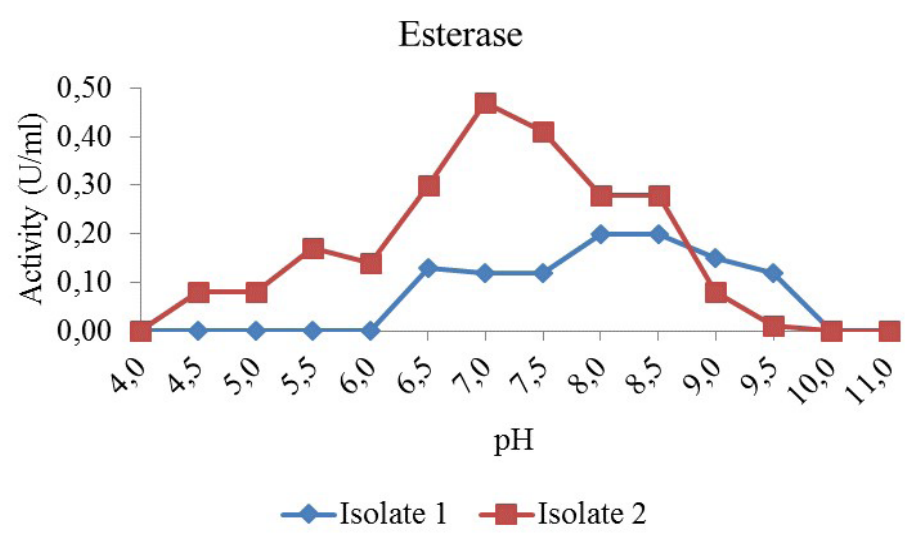

Figure 5. The graph of $\mathrm{pH}$ changes of esterase activity

Figura 5. Graficul modificărilor de pH ale activităţii esterazei

The highest activity of lipase was detected at pH 7.0 for isolate 1 and at $\mathrm{pH} 7.5$ for isolate 2 . It was observed that isolate 2 was active at $\mathrm{pH}$ 5.0-9.0 range, while isolate 1 was active at $\mathrm{pH}$ 5.0-7.5 range. Therefore, it was determined that isolate 1 had lipase activity in acidic, neutral and alkaline conditions (Figure 6).
Cea mai mare activitate a lipazei a fost detectată la pH 7,0 pentru izolatul 1 şi la pH 7,5 pentru izolatul 2. S-a observat că izolatul 2 a fost activ în intervalul de pH 5,0-9,0, iar izolatul 1 a fost activ în intervalul de pH 5,0-7,5. Prin urmare, s-a stabilit că la izolatul 1 activitatea lipazei a avut loc în condiţii acide, neutre şi alcaline (Figura 6). 
Lipase

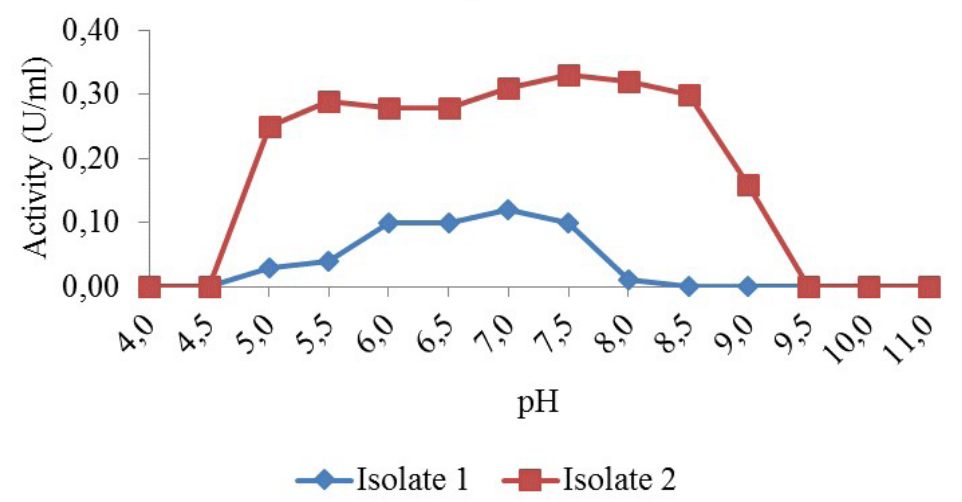

Figure 6. The graph of $\mathrm{pH}$ changes of lipase activity

Figura 6. Graficul modificărilor de pH ale activităţii lipazei

The highest activity of esterase was detected in $2.5 \mathrm{M} \mathrm{NaCl}$ for isolate 1 and in $3 \mathrm{M}$ $\mathrm{NaCl}$ for isolate 2. Both isolates were determined to have no esterase activity in $1 \mathrm{M} \mathrm{NaCl}$ (Figure 7).
Cea mai mare activitate a esterazei a fost detectată la $2,5 \mathrm{M} \mathrm{NaCl}$ pentru izolatul 1 şi la $3 \mathrm{M}$ $\mathrm{NaCl}$ pentru izolatul 2. Niciunul dintre izolate nu au avut activitate a esterazei la $1 \mathrm{M} \mathrm{NaCl}$ (Figura 7).

\section{Esterase}

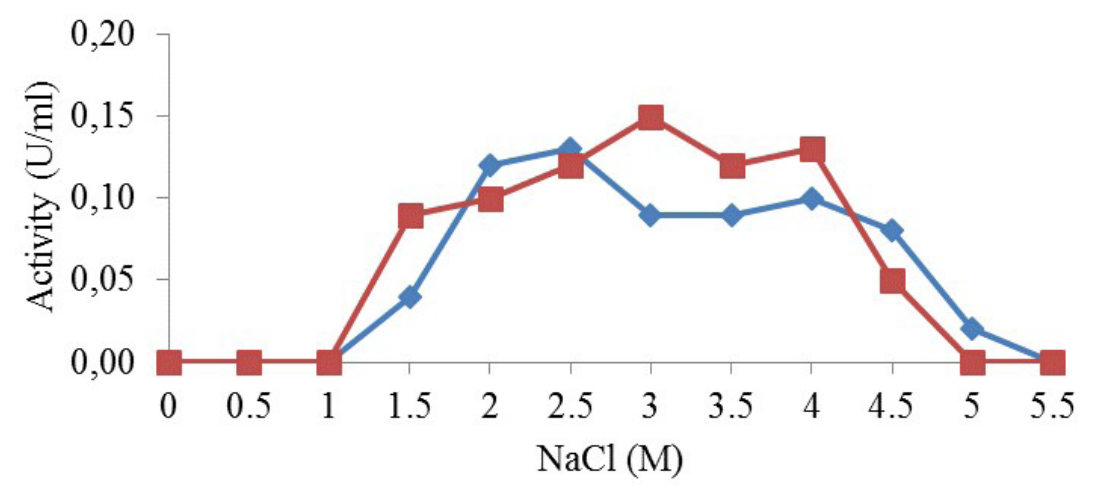

$\leadsto$-Isolate $1 \leadsto$-Isolate 2

Figure 7. The graph of $\mathrm{NaCl}$ changes of esterase activity

Figura 7. Graficul modificărilor de $\mathrm{NaCl}$ ale activităţii esterazei

The highest activity of lipase was detected in 2-3.5 $\mathrm{M}$ for isolate 1 and $2 \mathrm{M}$ for isolate 2. Isolates 1 and 2 were found to exhibit lipase activity in $1.5-4 \mathrm{M}$ and $0.5-4.5 \mathrm{M} \mathrm{NaCl}$, respectively. It was observed that isolate 2 had slight lipase activity in low concentrations of salts such as in $0.5 \mathrm{M}, 1.0 \mathrm{M}$ and $1.5 \mathrm{M} \mathrm{NaCl}$ (Figure 8).

Thus, optimal esterase activity was detected at $35^{\circ} \mathrm{C}, \mathrm{pH} 8,2.5 \mathrm{M} \mathrm{NaCl}$ for isolate 1 and at $35^{\circ} \mathrm{C}, \mathrm{pH} 7,3 \mathrm{M} \mathrm{NaCl}$ for isolate 2 . Additionally, the optimal lipase activity was detected at $40^{\circ} \mathrm{C}$, $\mathrm{pH} 7.0,2 \mathrm{M}-3.5 \mathrm{M} \mathrm{NaCl}$ for isolate 1 and at $35^{\circ} \mathrm{C}$, $\mathrm{pH} 7.5,2 \mathrm{M} \mathrm{NaCl}$ for isolate 2 .
Cea mai mare activitate a lipazei a fost detectată la 2-3,5 M pentru izolatul 1 şi la $2 \mathrm{M}$ pentru izolatul 2. Izolatele 1 şi 2 au prezentat activitate a lipazei la 1,5-4 M şi respectiv 0,5-4,5 M $\mathrm{NaCl}$. S-a observat că izolatul 2 a prezentat o uşoară activitate a lipazei la concentraţii scăzute de săruri, cum ar fi la 0,5 M, 1,0 M şi 1,5 M NaCl (Figura 8).

Astfel, activitatea optimă a esterazei a fost detectată la $35^{\circ} \mathrm{C}, \mathrm{pH} 8,2,5 \mathrm{M} \mathrm{NaCl}$ pentru izolatul 1 şi la $35^{\circ} \mathrm{C}, \mathrm{pH} 7,3 \mathrm{M} \mathrm{NaCl}$ pentru izolatul 2. În plus, activitatea optimă a lipazei a fost detectată la $40^{\circ} \mathrm{C}, \mathrm{pH} 7,0,2 \mathrm{M}-3,5 \mathrm{M} \mathrm{NaCl}$ pentru izolatul 1 şi la $35^{\circ} \mathrm{C}, \mathrm{pH} 7,5,2 \mathrm{M} \mathrm{NaCl}$ pentru izolatul 2. 


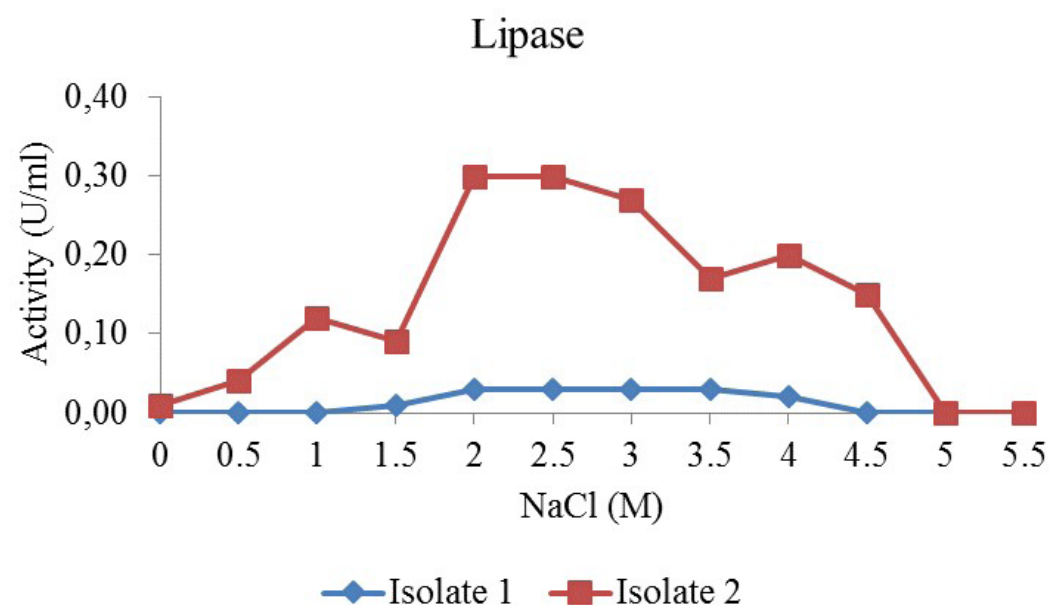

Figure 8. The graph of $\mathrm{NaCl}$ changes of lipase activity

Figura 8. Graficul modificărilor de $\mathrm{NaCl}$ ale activităţii lipazei

In the study which investigates the esterase and lipase activities of 5 halophilic archaeal strains, $p$-Nitrophenyl butyrate (pNPB) for esterase and p-nitrophenyl palmitate (pNPP) for lipase were used as substrates [37]. In the mentioned study, the maximum esterase activity was observed in reaction conditions of 3-4.5 M $\mathrm{NaCl}, \mathrm{pH} 8-8.5$ and $60-65^{\circ} \mathrm{C}$, and maximum lipase activity in $3.5-4 \mathrm{M} \mathrm{NaCl}$ and at $\mathrm{pH} 8$ and $45-60^{\circ} \mathrm{C}$. Moreover, it was also detected that the values of esterase activity were higher than those of lipase activity. It was found that our results related to optimal conditions were different from the above reported research results.

Bhatnagar et al. [26] examined lipolytic activity of halobacteria strain using similar substrates. The study showed that optimal conditions of Halobacteria strain were $3.5 \mathrm{M}$ $\mathrm{NaCl}, \mathrm{pH} 8,40^{\circ} \mathrm{C}$ for esterase and $4 \mathrm{M} \mathrm{NaCl}$, $\mathrm{pH} 7.540^{\circ} \mathrm{C}$ for lipase. They also suggest that esterase activity occurs faster than the lipase activity. Ozcan et al. [38] reported that optimal esterase and lipase activity of halophilic archaeal isolates were identified at $\mathrm{pH} 8.5$ in $3-4.5 \mathrm{M} \mathrm{NaCl}$. In addition, optimal temperature was stated as $50-55^{\circ} \mathrm{C}$ for esterase and as $60-65^{\circ} \mathrm{C}$ for lipase. Boutaiba et al. [39] investigated lipolytic activity of extremely halophilic Archaea Natronococcus sp. p-nitrophenyl palmitate (pNPP) was used as a substrate. They reported that optimal lipolytic activity was detected in $4 \mathrm{M} \mathrm{NaCl}, \mathrm{pH} 7$, at $50^{\circ} \mathrm{C}$. Thus, our research findings were found to be compatible with these results.
În cadrul unui studiu care investighează activitatea esterazei şi lipazei la 5 tulpini Archaea halofile, s-au utilizat ca substraturi p-nitrofenil butirat (pNPB) pentru esterază şi palmitat p-nitrofenil (pNPP) pentru lipază [37]. În cadrul studiului menţionat, activitatea maximă a esterazei a fost observată în condiţii de reacţie de 3-4,5 M NaCl, pH 8-8,5 şi 60-65 ${ }^{\circ} \mathrm{C}$, iar activitatea maximă a lipazei la 3,5-4 M NaCl, la pH 8 şi 45$60^{\circ} \mathrm{C}$. Mai mult decât atât, s-a observat, de asemenea, că valorile activităţii esterazei au fost mai mari decât cele ale activităţii lipazei. S-a constatat că rezultatele noastre legate de condiţiile optime au fost diferite de rezultatele cercetării prezentate mai sus.

Bhatnagar şi colab. [26] au examinat activitatea lipolitică a tulpinilor halobacteriilor folosind substraturi similare. Studiul a demonstrat că condiţiile optime ale tulpinilor halobacteriilor au fost de $3,5 \mathrm{M} \mathrm{NaCl}, \mathrm{pH} 8$, $40^{\circ} \mathrm{C}$ pentru esterază şi $4 \mathrm{M} \mathrm{NaCl}, \mathrm{pH} 7,5,40^{\circ} \mathrm{C}$ pentru lipază. De asemenea, aceștia sugerează că activitatea esterazei are loc mai rapid decât activitatea lipazei. Ozcan şi colab. [38] au raportat că activitatea optimă a esterazei şi a lipazei la izolatele Archaea halofile s-a identificat la pH 8,5 în 3-4,5 M NaCl. În plus, temperatura optimă a fost raportată la $50-55^{\circ} \mathrm{C}$ pentru esterază şi la $60-65^{\circ} \mathrm{C}$ pentru lipază. Boutaiba şi colab. [39] au investigat activitatea lipolitică a unei Archaea extrem halofilă, Natronococcus sp. S-a utilizat ca substrat palmitat $p$-nitrofenil (pNPP). Autorii au raportat că activitatea lipolitică optimă a

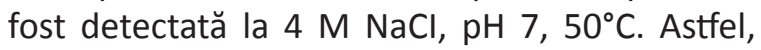
rezultatele cercetării noastre $\mathrm{s}$-au dovedit a fi compatibile cu aceste rezultate. 


\section{CONCLUSIONS}

In the study, firstly, it was found that isolate 1 was similar to Halomicrobium zhouii strain 144 and isolate 2 to Haloarchaeon strain 129 by $16 \mathrm{~S}$ rRNA gene sequence analysis. It was determined that both isolates were Gram negative and susceptible to novobiocin and bacitracin antibiotics. Thus, our research findings supported that isolates belong to the Archaea domain. It was revealed that two extremely halophilic Archaea also have lipolytic activity. Extremely Halophilic Archaea with lipolytic enzyme activities may cause fat migration which is undesirable on the raw hide and skin. If Archaea causing damage to the skin by lipolytic activities were identified, ad hoc chemicals could be used to control them.

Secondly, optimal esterase and lipase activity conditions of the two Extreme Halophilic Archaea were quantitatively determined. According to the research findings, the highest esterase $(4 \mathrm{U} / \mathrm{ml})$ and lipase $(1 \mathrm{U} / \mathrm{ml})$ activity values of isolate 1 were observed in supernatant on the $4^{\text {th }}$ day of growth. The highest esterase $(2.7 \mathrm{U} / \mathrm{ml})$ and lipase $(1.9 \mathrm{U} / \mathrm{ml})$ activity values of isolate 2 were determined in supernatant on the $3^{\text {rd }}$ day of growth. Optimal esterase activity was detected at $35^{\circ} \mathrm{C}, \mathrm{pH} 8$, and in $2.5 \mathrm{M} \mathrm{NaCl}$ for isolate 1 and at $35^{\circ} \mathrm{C}, \mathrm{pH} 7$, and in $3 \mathrm{M} \mathrm{NaCl}$ for isolate 2 . The optimal lipase activity was also determined at $40^{\circ} \mathrm{C}, \mathrm{pH} 7.5$, and in $2 \mathrm{M} \mathrm{NaCl}$ for isolate 1 and at $35^{\circ} \mathrm{C}, \mathrm{pH} 7$, and in $2 \mathrm{M} \mathrm{NaCl}$ for isolate 2 .

It was detected that esterase and lipase enzymes of isolate 2 were active at a wide $\mathrm{pH}$ range of 4.5-9.0 and 5.0-9.0, respectively. Thus, it was considered as an important finding that both esterase and lipase activity of isolate 2 have a wide $\mathrm{pH}$ range. Besides, it was also recorded as an important finding that isolate 2 exhibits lipase activity in a high salt concentration, e.g. in $4.5 \mathrm{M} \mathrm{NaCl}$, as well as in low salt concentration, e.g. in $0.5 \mathrm{M} \mathrm{NaCl}$. Esterase activity of isolate 2 was determined at a wide temperature range of $4-55^{\circ} \mathrm{C}$. Thus, these findings were considered important for industrial esterase and lipase production.

Finally, it was thought that the investigation of esterase and lipase enzymes of isolate 2 by advanced research methods and of their usability in industry would be useful. It should not be ignored that these isolates can be used as a source of lipolytic enzyme in several areas of the industry.

\section{CONCLUZII}

În cadrul studiului, s-a constatat, în primul rând, că izolatul 1 a fost similar tulpinii Halomicrobium zhouii 144 şi izolatul 2 similar tulpinii Haloarchaeon 129 în urma analizei secvenţei genei ARNr 16S. S-a stabilit că ambele izolate sunt Gram negative şi sensibile la novobiocină şi bacitracină. Astfel, rezultatele cercetării noastre sprijină faptul că izolatele aparţin domeniului Archaea. S-a demonstrat că cele două Archaea extrem halofile au, de asemenea, activitate lipolitică. Archaea extrem halofile cu activităţi enzimatice lipolitice pot provoca migraţia grăsimii, de nedorit la pielea brută. În cazul în care se identifică Archaea ce provoacă leziuni pe piele prin activităţile lipolitice, se pot folosi produse chimice ad-hoc pentru a le controla.

În al doilea rând, s-au determinat cantitativ condiţiile optime pentru activitatea lipazei şi esterazei în cazul celor două Archaea extrem halofile. În conformitate cu rezultatele cercetărilor, cele mai mari valori ale activităţii esterazei $(4 \mathrm{U} / \mathrm{ml})$ şi lipazei $(1 \mathrm{U} / \mathrm{ml})$ pentru izolatul 1 au fost observate în supernatant în patra zi de creştere. Cele mai mari valori ale activităţii esterazei $(2,7 \mathrm{U} / \mathrm{ml})$ şi lipazei $(1,9$ $\mathrm{U} / \mathrm{ml}$ ) pentru izolatul 2 au fost detectate în supernatant în treia zi de creştere. Activitatea optimă a esterazei a fost detectată la $35^{\circ} \mathrm{C}, \mathrm{pH}$ $8,2,5 \mathrm{M} \mathrm{NaCl}$ pentru izolatul 1 şi la $35^{\circ} \mathrm{C}, \mathrm{pH}$, $3 \mathrm{M} \mathrm{NaCl}$ pentru izolatul 2. Activitatea optimă a lipazei a fost determinată la $40^{\circ} \mathrm{C}, \mathrm{pH} 7,5,2 \mathrm{M}$ $\mathrm{NaCl}$ pentru izolatul 1 şi la $35^{\circ} \mathrm{C}, \mathrm{pH} \mathrm{7,2} \mathrm{M} \mathrm{NaCl}$ pentru izolatul 2.

S-a observat că enzimele esterază şi lipază din izolatul 2 au fost active într-o gamă largă de pH de 4,5-9,0, respectiv 5,0-9,0. Astfel, o constatare importantă a fost faptul că activităţile esterazei şi lipazei la izolatul 2 au avut loc într-o gamă largă de pH. În plus, o altă constatare importantă a fost faptul că izolatul 2 prezintă o activitate a lipazei într-o concentraţie mare de sare, de exemplu, la $4,5 \mathrm{M} \mathrm{NaCl}$, precum şi într-o concentraţie scăzută de sare, de ex. la $0,5 \mathrm{M} \mathrm{NaCl}$. Activitatea esterazei la izolatul 2 a fost determinată într-o gamă largă de temperaturi, $4-55^{\circ} \mathrm{C}$. Astfel, aceste descoperiri au fost considerate importante pentru producţia industrială de esterază şi lipază.

În cele din urmă, s-a considerat utilă investigarea enzimelor esterază şi lipază ale izolatului 2 prin metode avansate de cercetare şi a gradului de utilizare a acestora în industrie. Nu trebuie ignorat faptul că aceste izolate pot fi utilizate ca sursă de enzime lipolitice în mai multe domenii ale industriei. 


\section{REFERENCES}

1. Bilgi, S.T., Meriçli Yapıcı, B., Yapici, A.N., Determination of Bacterial and Fungal Numbers in Floats of Pre-Tanning Operations, Afr J Biotechnol, 2009, 8, 8, 1602-1607.

2. Kanagaraj, J., John Sundar, V., Muralidharan, C., Sadulla, S., Alternatives to sodium chloride in prevention of skin protein degradation-a case study, J Clean Prod, 2004, 13, 825-831.

3. Rao, B.R., Henrickson L., Short-term preservation of cattle hide, J Am Leather Chem As, 1983, 78, 48-53.

4. Vankar, P.S., Dwivedi, A.K., Raw Skin Preservation Through Sodium Salts-A Comparative Analysis, Desalination, 2009, 249, 158-162.

5. Yapici, A.N., The Effect of Using a Fungicide along with Bactericide in the Main Soaking Float on Microbial Load, Afr J Biotechnol, 2008, 7, 21, 3922-3926.

6. Yapıcı, A.N., Meriçli Yapıcı, B., Karaboz I., Tozan, M., An in vitro Assessment of the Effectiveness of Some Bactericides on Bacteria Isolated from Soaking Float, Asian J Chem, 2009, 21, 2, 1521-1525.

7. Thorstensen, T.C., Practical Leather Technology (4th.ed.). Kriger Publishing Company Krigerdrive, Malabar, Florida, 1993, 340p.

8. Türkan, M.F., Aslan, A., Yapıcı, A.N., Meriçli Yapıcı, B., Bilgi, S.T., Assessment of Antimicrobial Activity of Natural Leathers Treated with Pseudevernia furfuracea (L.) Zopf Exstracts, Tekstil ve Konfeksiyon, 2013, 23, 2, 176-180.

9. Ulaş, G., Meriçli Yapıcı, B., Yapıcı, A.N., Evaluation of the Antimicrobial Activity of Some Commercial Vegetable Extracts Used in Tanneries, Ekoloji, 2014, 92, 45-50.

10. Menteş Çolak, S., Meriçli Yapıcı, B., Yapıcl, A.N., Determination of Antimicrobial Activity of Tannic Acid in Pickling Process, Rom Biotech Lett, 2010, 15, 3, 5325-5330.

11. Meriçli Yapıcı, B., YapıcI, A.N. and Keçici, E., The Effect of Reuse of Unhairing-Liming Residual Floats Through Regeneration on the Microorganisms Number, Afr J Biotechnol, 2008, 7, 17, 3077-3081.

12. DasSarma, S., Coker, J.A., ve DasSarma, P., Archaea - Overview, in: Schaechter, M. (Ed.), Desk Encyclopedia of Microbiology (2nd ed), Academic Press, 2010, 118-139.

13. Kushner, D.J., The Halobacteriaceae, in: Woese, C.R., Wolfe R.S. (Ed.), The bacteria. A treatise on structure and function. Archaebacteria. Vol 8. Academic Press, London, 1985, 171-214.

14. Bilgi, S.T., Mericli Yapici, B., Karaboz, I., Determination of Hydrolytic Enzyme Capabilities of Halophilic Archaea Isolated from Hides and Skins and Their Phenotypic and Phylogenetic Identification, J Am Leather Chem As, 2015, 110, 2, 33-42.

15. Wiseman, A., Introduction to Principles, in: Handbook of Enzyme Biotechnology, Wiseman, A. (Ed.) 3rd Edn., Ellis Horwood Ltd., T.J. Press Ltd., Padstow, Cornwall, UK, 1995, 3-8.

16. Eren Kıran, Ö., Çömlekçioğlu, U., Dostbil, N., Bazı Mikrobiyal Enzimler ve Endüstrideki Kullanım Alanları (in Turkish), KSÜ, Fen ve Mühendislik Dergisi, Kahramanmaraş, 2006, 9, 2-19.

17. Afendra, A.S., Vargas, C., Nieto, J.J., Drainas, C., Gene Transfer and Expression of Recombinant Proteins in Moderately Halophilic Bacteria, Methods Mol Biol, 2004, 267, 209-223.

18. Dussault, H.P., An Improved Technique For Stainin Red Halophilic Bacteria, J Bacteriol, 1955, 70, 484-485.

19. Montalvo-Rodriguez, R., Vreeland, R.H., Oren, A., Kessel, M., Betancourt, C., Lopez-Gariga, J., Halogeometricum borinquense gen. nov., sp. nov., A Novel Halophilic Archaeon From Puerto Rico. Int J Syst Bacteriol, 1998, 48, 1305-1312.

20. Birbir, M., Sesal, C., Extremely Halophilic Bacterial Communities in Serflikoçhisar Salt Lake in Turkey, Turk J Biol, 2003, 27, 7-22.

21. Birbir, M., Cali, B., Mertoglu, B., Bardavid, R.E., Oren, A., Ogmen, M.R., Ogan, A., Extremely Halophilic Archaea from Tuz Lake, Turkey, and the Adjacent Kaldirim and Kayacik salterns, World J Microbiol Biotechnol, 2007, 23, 309-316.

22. Dyall-Smith, M., The Halohandbook-Protocols for Haloarchaeal Genetics. Version 7. 2008, 144p.

23. Lane, D.J., 16S/23S rRNA Sequencing, in Stackebrandt E., Goodfellow M. (eds), Nucleic Acid Techniques in Bacterial Systematics, John Wiley and Sons, New York, 1991, 115-175. 
GÖZDE TURHAN BILGI, BINNUR MERIÇLI YAPICI, SADI TURGUT BILGI

24. Lueders, T., Manefield, M., Friedrich, M.W., Enhanced Sensitivity of DNA- and rRNA-Based Stable Isotope Probing by Fractionation and Quantitative Analysis Of Isopycnic Centrifugation Gradients, Environ Microbiol, 2004, 6, 73-78.

25. Elevi, R., Assa, P., Birbir, M., Ogan, A., Oren, A., Characterization of Extremely Halophilic Archaea Isolated from the Ayvalik Saltern, Turkey, World J Microbiol Biotechnol, 2004, 20, 719-725.

26. Bhatnagar, T., Boutaiba, S., Hacene, H., Cayol, J.L., Fardeau, M.L., Ollivier, B., Baratti, J.C., Lipolytic activity from Halobacteria: Screening and hydrolase production, FEMS Microbiol Lett, 2005, 248, 133-140.

27. Sanchez-Porro, C., Martin, S., Mellado, E., Ventosa, A., Diversity of Moderately Halophilic Bacteria Producing Extracellular Hydrolytic Enzymes, J Appl Microbiol, 2003, 94, 295-300.

28. Kouker, G., Jaeger, K.E., Specific and Sensitive Plate Assay for Bacterial Lipases, Appl Environ Microbiol, 1987, 53, 1, 211-213.

29. Anonymous, Rhodamine B Agar Preparation Procedure (b.t.). Access August 7, 2009, from http:// www.alken-murray.com/lipase.html, 2009.

30. Camacho, R.M., Mateos, J.C., Gonzalez-Reynoso Orfil., Prado L.A., Cordova, J., Production and Characterization of Esterase and Lipase from Haloarcula marismortui, J Ind Microbiol Biotechnol, 2009, 36, 901-909.

31. Beisson, F., Tiss, A., Riviere, C., Verger, R., Methods for Lipase Detection and Assay: a critical Review, Eur J Lipid Sci Technol, 2000, 133-153.

32. Holmes, M.L., Dyall-Smith, M.L., Mutations in DNA gyrase Results in Novobiocin Resistance in Halophilic Archaebacteria, J Bacteriol, 1991, 173, 642-648.

33. Çetinkuş, K., Çamaltı Tuzlası Halofilik Mikroorganizmaların İzolasyonu ve Karakterizasyonu (in Turkish), MSc Dissertation, Anadolu University. Eskişehir, Turkey, 2007.

34. Yıldız, E., Özcan, B., Çalışkan, M., Isolation, Characterization and Phylogenetic Analysis of Halophilic Archaea from a Salt Mine in Central Anatolia (Turkey), Pol J Microbiol, 2012, 61, 2, 111-117.

35. Yang, X., Cui, H.L., Halomicrobium zhouii sp. nov., A Halophilic Archaeon from a Marine Solar Saltern, Int J Syst Evol Microbiol, 2012, 62, 1235-1240.

36. He, M., Zou, Z., Cai, L., Wang, G., Haloarchaea and Halophilic Bacteria in Two Hypersaline Soils of Jiangsu Province, China, http://www.ncbi.nlm.nih.gov, 2007.

37. Ozcan, B., Ozyilmaz, G., Cokmus, C., Caliskan, M., Characterization of Extracellular Esterase and Lipase Activities from Five Halophilic Archaeal Strains, J Ind Microbiol Biotechnol, 2009, 36, 105-110.

38. Özcan, B., Özyılmaz, G., Cihan, A., Çökmüş, C., Çalışkan, M., Phylogenetic Analysis and Characterization of Lipolytic Activity of Halophilic Archaeal Isolates, Microbiology, 2012, 81, 2, 186-194.

39. Boutaiba, S., Bhatnagar, T., Hacene, H., Mitchell, D.A., Baratti, J.C., Preliminary Characterisation of a Lipolytic Activity from an Extremely Halophilic Archaeon, Natronococcus sp., J Mol Catal B-Enzym, 2006, 41, 21-26.

Article received/Data primirii articolului: 16.10.2016

Accepted/Acceptat la data: 18.11.2016 